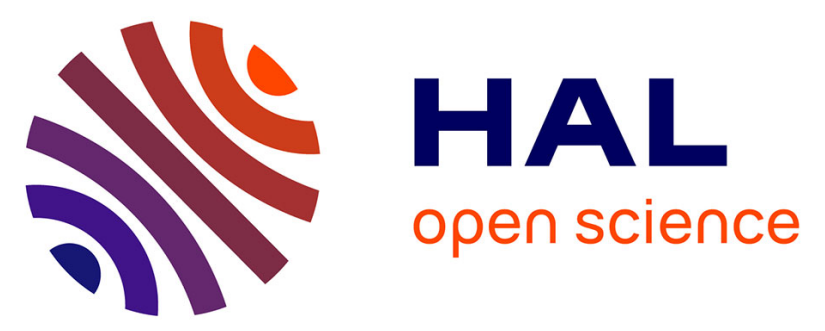

\title{
Anti-inflammatory activity of coumarins from Ligusticum lucidum Mill. subsp. cuneifolium (Guss.) Tammaro (Apiaceae)
}

Luigi Menghini, Francesco Epifano, Salvatore Genovese, M. Carla Marcotullio, Silvio Sosa, Aurelia Tubaro

\section{To cite this version:}

Luigi Menghini, Francesco Epifano, Salvatore Genovese, M. Carla Marcotullio, Silvio Sosa, et al.. Anti-inflammatory activity of coumarins from Ligusticum lucidum Mill. subsp. cuneifolium (Guss.) Tammaro (Apiaceae). Phytotherapy Research, 2010, 24 (11), pp.1697. 10.1002/ptr.3170 . hal00599824

\section{HAL Id: hal-00599824 \\ https://hal.science/hal-00599824}

Submitted on 11 Jun 2011

HAL is a multi-disciplinary open access archive for the deposit and dissemination of scientific research documents, whether they are published or not. The documents may come from teaching and research institutions in France or abroad, or from public or private research centers.
L'archive ouverte pluridisciplinaire HAL, est destinée au dépôt et à la diffusion de documents scientifiques de niveau recherche, publiés ou non, émanant des établissements d'enseignement et de recherche français ou étrangers, des laboratoires publics ou privés. 
Anti-inflammatory activity of coumarins from Ligusticum lucidum Mill. subsp. cuneifolium (Guss.) Tammaro (Apiaceae)

\begin{tabular}{|c|c|}
\hline Journal: & Phytotherapy Research \\
\hline Manuscript ID: & PTR-07-0987 \\
\hline Wiley - Manuscript type: & Full Paper \\
\hline $\begin{array}{r}\text { Date Submitted by the } \\
\text { Author: }\end{array}$ & 07-Nov-2007 \\
\hline Complete List of Authors: & $\begin{array}{l}\text { Menghini, Luigi; University "G. d'Annunzio", Dipartimento di Scienze } \\
\text { del Farmaco } \\
\text { Epifano, Francesco; University "G. d'Annunzio", Dipartimento di } \\
\text { Scienze del Farmaco } \\
\text { Genovese, Salvatore; University of Perugia, Dipartimento di chimica } \\
\text { e Tecnologia del Farmaco } \\
\text { Marcotullio, M. Carla; University of Perugia, Dipartimento di chimica } \\
\text { e Tecnologia del Farmaco } \\
\text { Sosa, Silvio; University of Trieste, Department of Materials and } \\
\text { Natural Resources } \\
\text { Tubaro, Aurelia; University of Trieste, Department of Materials and } \\
\text { Natural Resources }\end{array}$ \\
\hline Keyword: & Ligusticum lucidum, coumarins, Anti-inflammatory activity \\
\hline
\end{tabular}

\section{s) ScholarONE" \\ Manuscript Central}




\section{Anti-inflammatory activity of coumarins from Ligusticum lucidum Mill. subsp. cuneifolium (Guss.) Tammaro (Apiaceae)}

Luigi Menghini, ${ }^{a *}$ Francesco Epifano, ${ }^{\mathrm{a}}$ Salvatore Genovese, ${ }^{\mathrm{b}}$ Maria C. Marcotullio, ${ }^{\mathrm{b}}$ Silvio Sosa $^{c}$ and Aurelia Tubaroc

aDipartimento di Scienze del Farmaco, University “G. D’Annunzio” of Chieti-Pescara, Via dei Vestini 31, 66013 Chieti Scalo (Italy); ${ }^{b}$ Dipartimento di Chimica e Tecnologia del Farmaco, Sezione di Chimica Organica, University of Perugia, Via Liceo, 06123 Perugia (Italy); ${ }^{c}$ Department of Materials and Natural Resources, University of Trieste, Via A. Valerio 6, 34127 Trieste (Italy);

\footnotetext{
*Corresponding author: Dipartimento di Scienze del Farmaco, University "G. D’ Annunzio" of Chieti-Pescara, Via dei Vestini 31, 66013 Chieti Scalo (Italy); tel +3908713554655, fax: +3908713554655, e-mail: lmenghini@unich.it
} 


\begin{abstract}
Four coumarin derivatives [selidinin 1, (+)-praeruptorin A 2, visnadin 3 and (R)-(+)-7(2',3'-epoxy-3'-methylbutoxy)-coumarin 4] were isolated from the aerial parts of Ligusticum lucidum Mill. subsp. cuneifolium (Guss.) Tammaro (Apiaceae). This is the first report on identification of these compounds in Ligusticum genus. Their topical antiinflammatory activity was evaluated as inhibition of the Croton oil-induced ear dermatitis in mice. Each compound induced a significant oedema reduction and compound 4 exerted an effect similar to that of the reference drug indomethacin.
\end{abstract}

\title{
Keywords
}

Ligusticum lucidum, coumarins, anti.inflammatory activity.

\section{Introduction}

The Apiaceae family includes many plants distributed all over the world and a great number of these species are used as traditional ethnomedical remedies or food. Previous studies on coumarin occurrence in the family of Apiaceae, one of the richest source of these compounds, showed a profile comprising a wide range of phenylpropanoids, in particular substituted coumarins, fused furano- and pyranocoumarins (Wierzchowska-Renke 1974) and finally prenyloxycoumarins (Curini 2006). Nevertheless, little information about the chemical constituents within the genus Ligusticum is available. In fact, a previous phytochemical investigation on the whole plant of Ligusticum lucidum Mill. reported only its fatty acid composition (Kleiman 1982). To the best of our knowledge, no other phytochemical studies have been carried out on this plant to date and in particular no 
investigastions were done on the subsp. cuneifolium.

\section{Materials and methods}

Ligusticum lucidum Mill. subsp. cuneifolium (Guss.) Tammaro (Apiaceae) is a perennial herb living on rocky calcareous gravels of the Majella Mountains (Abruzzo, Italy), at altitudes ranging from 1000 to $1300 \mathrm{~m}$. It's an endemic entity and to date there is no record about its use in local ethnomedical traditions.

Aerial parts of L. lucidum subsp. cuneifolium were collected at flowering stage in its native "locus classicus" (Tammaro 1989), at the end of July 2005. Identification of the plant was carried out by Prof. Fernando Tammaro from the Botanical Section of the Faculty of Biotechnology of University of L'Aquila, Italy. A voucher specimen (No. 2871/1) was deposited in the Herbarium (AQUI) of University of L'Aquila, Italy.

The structure of compounds $\mathbf{1 - 4}$ was established by spectroscopic and spectrometry methods, particularly NMR and GC-MS techniques, and confirmed by comparison with the literature data (Goswani 2006, Liu 2004, Ikeshiro 1992, Gray 1981).

The topical anti-inflammatory activity of these natural compounds was evaluated using the Croton oil-induced ear oedema test in mice as experimental model of inflammation, in comparison to that of the non steroidal anti-inflammatory drug (NSAID) indomethacin (Tubaro 1685).

Male CD-1 mice (28-32 g; Harlan Italy, Udine, Italy) were anaesthetised with ketamine hydrochloride (145 mg/kg, intraperitoneally; Virbac, Milan, Italy). Inflammation was induced on the right ear (surface: about $1 \mathrm{~cm}^{2}$ ) applying $80 \mu \mathrm{g}$ of Croton oil (Sigma Chemical Co., St. Louis, USA) dissolved in acetone. Control animals received only the 
irritant, whereas the others received both the irritant and the compounds under study, dissolved in acetone. After 6 hours, mice were killed to excise a plug $(6 \mathrm{~mm} \varnothing)$ from both the treated and untreated ears. Oedema was quantified as weight difference between the two plugs. The anti-inflammatory activity was expressed as percent of oedema reduction in mice treated with the compounds under test with regard to control mice. Oedema values, expressed as mean \pm standard error of the mean, were analyzed by one-way analysis of variance followed by Dunnett's test for multiple comparison of unpaired data. Significance was considered for probability levels lower than 0.05. Experiments complied with the Italian D.L. n. 116 of January 1992 and associated guidelines in the European Communities Council Directive of 24 November 1986.

\section{Results and discussion}

We report herein the isolation, structural characterization and anti-inflammatory activity of four coumarins from aerial parts of L. lucidum subsp. cuneifolium

Compounds 1-4 (Figure 1) were isolated for the first time from the genus Ligusticum. Among them selinidin $\mathbf{1}$ is known to occur in other species of Ligusticum(Gupta 1975). Selidinin 1, (+)-Praeruptorin A 2 and visnadin 3 are common in other genera belonging to the family of Apiaceae, such Ammi (Duarte 1997), Angelica (Akihisa 2003), Peucedanum (Chen 1996) and Selinum (Seshadri 1967). On the contrary, (R)-(+)-7-(2',3'-epoxy-3'methylbutoxy)-coumarin $\mathbf{4}$ has been previously isolated only form three species belonging to genus Coleonema (Rutaceae), namely C. album (Gray 1981), C. aspalathoides and C. calycinum (Gray 1986), being identified in the genus Ligusticum for the first time. 
Results obtained for topical anti-inflammatory activity tests revealed that each coumarin reduced the oedematous response to a certain extent at the dose of $0.3 \mu \mathrm{mol} / \mathrm{cm}^{2}$ (Table 1). In particular, the most active compound, (R)-(+)-7-(2',3'-epoxy-3'-methylbutoxy)-coumarin 4, induced $68 \%$ oedema reduction, exerting an effect higher than that of the same dose of the NSAID indomethacin (58\% oedema reduction). Oedema reductions provoked by the other coumarins ranged between 22\% [(+)-praeruptorin A 2] and $43 \%$ (visnadin 3)

Thus, the anti-inflammatory activity of these compounds appears to be modulated by the substituents on their aromatic ring. In particular, the presence of the 7-(2',3'-epoxy-3'methylbutoxy) group (coumarin 4) is accompanied by a high anti-inflammatory activity (68 $\%$ oedema reduction) whereas that of a saturated pyrano-fused ring (coumarins 1-3) is associated to a lower effect (22-43\% oedema reduction). The substituents on the pyrane ring seem to slightly influence the antiphlogistic effect of these compounds as well. Indeed, a significant increase of activity can be observed in visnadin 3 (43\% oedema reduction), characterised by the presence of 3'- $\beta$-O-dihydroangeloyl and 4'- $\beta$-O-acetyl residues, with respect to selinidin $\mathbf{1}$ or (+)-praeruptorin A $\mathbf{2}(27 \%$ or $22 \%$ oedema reduction, respectively), characterized by an $\alpha$-acyl configuration in the same positions [3'- $\alpha-\mathrm{O}-$ angeloyl (1 and 2) and 4'-O-acetyl (2)].

In conclusion, these findings suggest (R)-(+)-7-(2',3'-epoxy-3'-methylbutoxy)-coumarin 4 as a potential lead compound of a novel class of anti-inflammatory agents. Studies to elaborate a synthetic route to obtain 4 in sufficient amounts to get further insights into its mechanism of action and to synthesize structural analogues of $\mathbf{4}$ for in vitro and in vivo studies on their anti-inflammatory properties are in progress in our laboratories. 


\section{Experimental procedures}

Air-dried and finely powdered aerial parts (100 g) of L. lucidum subsp. cuneifolium were defatted with $n$-hexane $(2 \times 200 \mathrm{~mL})$ and subsequently extracted with $\mathrm{CH}_{2} \mathrm{Cl}_{2}(2 \times 400 \mathrm{~mL})$ by exhaustive maceration to give $2.1 \mathrm{~g}$ of dry extract. The extract was subjected to silica gel chromatography using $\mathrm{CH}_{2} \mathrm{Cl}_{2}$ and increasing polarity mixtures of $\mathrm{CH}_{2} \mathrm{Cl}_{2} / \mathrm{MeOH}$ (99.5:0.5 to $97: 3)$ as eluents. Two main fractions were obtained (180 $\mathrm{mg}$ and $130 \mathrm{mg}$, respectively) and subsequently purified by preparative TLC on 20 x $20 \mathrm{~cm}$ silica $60 \mathrm{~F}_{254}$ gel-coated glass sheets with $\mathrm{CH}_{2} \mathrm{Cl}_{2} / \mathrm{MeOH}$ 99.5:0.5 and 99:1 mixtures as mobile phases respectively, yielding compounds $\mathbf{1}(16 \mathrm{mg}), \mathbf{2}(11 \mathrm{mg}), \mathbf{3}$ (8 $\mathrm{mg})$ and $\mathbf{4}(11 \mathrm{mg})$.

Selinidin (1): white solid; mp: $97-98^{\circ} \mathrm{C}$; IR (KBr): 1655, $1630 \mathrm{~cm}^{-1} ;{ }^{1} \mathrm{H} \mathrm{NMR} ;{ }^{6}{ }^{13} \mathrm{C}$ NMR; ${ }^{6}$ Anal. Calcd. for $\mathrm{C}_{19} \mathrm{H}_{20} \mathrm{O}_{5}: \mathrm{C}, 69.50 ; \mathrm{H}, 6.14 ; \mathrm{O}, 24.36$. Found C, 69.47, H, 6.12; O, 24.38 .

(+)-Praeruptorin A (2): white solid; mp: 152 - $154^{\circ} \mathrm{C}$; IR (KBr): 1680, 1650, $1635 \mathrm{~cm}^{-1}$; ${ }^{1} \mathrm{H}$ NMR; ${ }^{13} \mathrm{C} \mathrm{NMR} ;{ }^{7}$ Anal. Calcd. for $\mathrm{C}_{21} \mathrm{H}_{22} \mathrm{O}_{7}$ : C, 65.28; H, 5.74; O, 28.98. Found C, 65.27, H, 5.72; O, 28.95.

Visnadin (3): white solid; white solid; mp: $86-87^{\circ} \mathrm{C}$; IR (KBr): $1685,1680,1630 \mathrm{~cm}^{-1} ;{ }^{1} \mathrm{H}$ NMR ${ }^{8}{ }^{13} \mathrm{C}$ NMR $;{ }^{8}$ Anal. Calcd. for $\mathrm{C}_{21} \mathrm{H}_{24} \mathrm{O}_{7}: \mathrm{C}, 64.94 ; \mathrm{H}, 6.23 ; \mathrm{O}, 28.83$. Found C, 64.97, H, 6.22; O, 28.80.

(R)-(+)-7-(2',3'-epoxy-3'-methylbutoxy)-coumarin (4): white solid; mp: 102 - $104^{\circ} \mathrm{C}$; IR (KBr): $1640 \mathrm{~cm}^{-1} ;{ }^{1} \mathrm{H} \mathrm{NMR} ;{ }^{13} \mathrm{C} \mathrm{NMR}\left(50 \mathrm{MHz}, \mathrm{CDCl}_{3} \delta\right)$ 18.7, 24.4, 57.8, 60.7, 68.4, 
101.6, 112.2, 112.6, 113.3, 128.5, 143.1, 155.5, 160.2, 160.9; Anal. Calcd. for $\mathrm{C}_{14} \mathrm{H}_{14} \mathrm{O}_{4}$ : C, 68.28; H, 5.73; O, 25.99. Found C, 68.26, H, 5.71; O, 25.98.

\section{Acknowledgements}

Authors wish to acknowledge the financial support from Regione Abruzzo (L.R. 35/97) Project "Tutela della Biodiversita", MIUR (Rome, Italy) and Prof. Fernando Tammaro for plant identification. 


\section{Reference}

Akihisa T, Tokuda H, Ukiya M, Iizuka M, Schneider S, Ogasawara K, Mukainaka T, Iwatsuki K, Suzuki T, Nishino H. 2003. Chalcones, coumarins, and flavanones from the exudate of Angelica keiskei and their chemopreventive effects. Cancer Lett: 201, 133-137 and references cited herein.

Chen IS, Chang CT, Sheen WS, Teng CM, Tsai IL, Duh CY, Ko FN. 1996. Coumarins and antiplatelet aggregation constituents from Formosan Peucedanum japonicum. Phytochemistry: 41, 525-530 and references cited herein.

Curini M, Cravotto G, Epifano F, Giannone G. 2006. Chemistry and biological activity of natural and synthetic prenyloxycoumarins. Curr Med Chem: 13, 199-222 and references cited herein.

Duarte J, Vallejo I, Perez-Vizcaino F, Jimenez R, Zarzuelo A, Tamargo J. 1997. Effects of visnadine on rat isolated vascular smooth muscles. Planta Med: 63, 233-236 and references cited herein.

Goswani S, Gupta VK, Raina S, Gupta BD. 2006. Selinidin: crystal structure generated by C-H $\cdots \mathrm{O}, \mathrm{C}-\mathrm{H} \cdots \pi$ and $\pi-\pi$ interactions. $J$ Chem Crystall: 36, 117-122.

Gray AI, Meegan CJ, O'Callaghan NB. 1986. Coumarins from two Coleonema species. Phytochemistry: 26, 257.

Gray AI. 1981. New coumarins from Coleonema album. Phytochemistry: 20, 1711-1713. Gupta BD, Banerjee SK, Handa KL. 1975. Coumarins of Ligusticum elatum. Phytochemistry: 14, 598. 
Ikeshiro Y, Mase I, Tomita Y. 1992 Dihydropyranocoumarins from roots of Peucedanum japonicum. Phytochemistry: 31, 4303-4306.

Kleiman R, Spencer GF. 1982. earch for new industrial oils: XVI. Umbelliflorae - seed oils rich in petroselinic acid. J Am Oil Chem Soc: 59, 29-38.

Liu R, Feng L, Sun A, Kong L. 2004. Preparative isolation and purification of coumarins from Peucedanum praeruptorum Dunn by high-speed counter-current chromatography. $J$ Chromatogr A: 1057, 89-94.

revisited. Agents Actions: 17, 347-349.

Seshadri TR, Sood MS. 1967. Absolute configuration of selinidine, vaginidin, and related compounds Curr Sci: 36, 563-565.

Tammaro F. 1989. Re-identification and characterization of Ligusticum cuneifolium Guss., Umbelliferae (gr.L.lucidum Miller), a neglected endemic entity from C. Italy. Annali Bot: 47, 215-225.

Tubaro A, Dri P, Del Bello G, Zilli C, Della Loggia R. 1985. The Croton oil ear test Wierzchowska-Renke K. 1974. Preliminary studies on coumarin compounds in plants of the Umbelliferae family. Acta Pol. Pharm. 31, 225-232. 
Table 1. Anti-inflammatory activity of coumarins 1-4 (administered dose: $0.3 \mu \mathrm{mol} / \mathrm{cm}^{2}$ ).

\begin{tabular}{ccccc}
\hline Compound & $\mathrm{N}^{\circ}$. animals & Dose & Oedema $(\mathrm{mg})$ & $\%$ \\
& & $\left(\mu \mathrm{mol} / \mathrm{cm}^{2}\right)$ & Mean \pm S.E. & Reduction \\
\hline Controls & 10 & -- & $6.9 \pm 0.2$ & -- \\
$\mathbf{1}$ & 10 & 0.3 & $5.1 \pm 0.3^{*}$ & 27 \\
$\mathbf{2}$ & 10 & 0.3 & $5.4 \pm 0.4^{*}$ & 22 \\
$\mathbf{3}$ & 10 & 0.3 & $3.9 \pm 0.3^{*}, * *$ & 43 \\
& 10 & 0.3 & $2.2 \pm 0.2^{*}$ & 68 \\
\hline & 10 & 0.3 & $2.9 \pm 0.3^{*}$ & 58 \\
\hline
\end{tabular}

${ }^{*} \mathrm{p}<0.05$ at the analysis of variance, as compared with controls;

$.{ }^{* *} \mathrm{p}<0.05$ at the analysis of variance, as compared with compounds $\mathbf{1}$ or $\mathbf{2}$. 


\section{Figure 1}

Coumarins isolated from Ligusticum lucidum: selinidin 1, (+)-praeruptorin A 2, visnadin 3, and a prenyloxycoumarin, (R)-(+)-7-(2',3'-epoxy-3'-methylbutoxy)-coumarin 4.<smiles>[R]C1c2c(ccc3ccc(=O)oc23)OC(C)(C)C1[R]</smiles>

$$
\begin{array}{ll}
1 \mathbf{R}^{1}=\alpha \text {-O-angeloyl, } & \mathbf{R}^{2}=-\mathbf{H} \\
2 \mathbf{R}^{1}=\alpha \text {-O-angeloyl, } & \mathbf{R}^{2}=-\alpha \text {-OAc } \\
3 \mathbf{R}^{1}=\beta \text {-O-dihydroangeloyl, } & \mathbf{R}^{2}=-\beta \text {-OAc }
\end{array}
$$<smiles>CC1(C)OC1COc1ccc2ccc(=O)oc2c1</smiles> 